\title{
SCIENTIFIC SUBSTANTIATION OF THE PRODUCT RANGE RENEWAL MODEL FOR MANUFACTURING PHARMACEUTICAL ENTERPRISE
}

\author{
(C) A. Kotvitska, V. Kostiuk
}

У сучасних умовах загострення конкуренції на вітчизняному фармацевтичному ринку, збільшення вартості наукових розробок та інвестииій ФП, підвищення рівня вимог і потреб споживачів ЛЗ, використання вітчизняними виробниками ліків інновачійних підходів до формування товарного асортименту, який дозволить забезпечити підприємству стійку ринкову позицію, економічну стабільність і стратегічний розвиток поряд із забезпеченням наявності на ринку Украӥни необхідних та доступних ЛЗ вітчизняного виробництва набуває особливої актуальності.

Мета. Розробка моделі оновлення товарного асортименту на виробничому ФП та ї опрацювання на прикладі сегменту нестероїднх протизапальних препаратів.

Методи. Під час дослідження використано системний, аналітичний та логічний методи аналізу.

Результати. На підставі систематизації одержаних результатів організаційно-економічних, маркетингових та фармакоекономічних досліджень фармацевтичного ринку обтрунтовано та розроблено модель оновлення товарного асортименту на виробничому ФП, щяо складається з п'яти послідовних етапів. Кожний етап запропонованої моделі передбачає проведення наукових досліджень організаційноекономічного спрямування та визначення результативних показників.

Висновки. Розроблена модель оновлення товарного асортименту на виробничому ФП може бути рекомендована як ефективна система підтримки прийняття фармацевтичною організацією обтрунтованих управлінських рішень у сфері маркетингу, щьо, на нашу думку, дозволить зменшити витрати $i$ значно підвишить ефективність ї̈ діяльності

Ключові слова: фармачевтичне підприємство, товарний асортимент, фармачевтичний ринок, маркетингові дослідження

\section{Introduction}

At the recent stage of development of the national pharmaceutical market, the activity of manufacturing pharmaceutical enterprises (PE) is substantially complicated by scientific and technological progress acceleration, economy globalization, state regulation influence, and raising the level of requirements and needs of consumers. One of the most important mechanisms to ensure the enterprise competitiveness is its assortment policy, the main purpose of which is formation of such type of nomenclature, which allows providing the company with a stable market position, economic stability and strategic development $[1,2]$.

That is why the actual direction of pharmaceutical companies is to improve its own assortment policy in order to ensure the availability of necessary and affordable national drugs in Ukrainian pharmaceutical market.

The low efficiency of many national PE, especially under economic crisis conditions, is due to a number of factors, one of which is the lack of effective managing mechanisms for brand portfolio and flexible product policy formation. In this regard, under the current conditions of business activity, the issue of correct choice of drugs assortment, their correlation, expediency and timeliness of implementation into production and market entry, adaptation of the product portfolio to the target market segments become of particular relevance [3,4]

2. Formulation of the problem in a general way, the relevance of the theme and its connection with important scientific and practical issues

The modern Ukrainian pharmaceutical market is a complex, multi-level dynamically developing system.
Among the main economic features of the national pharmaceutical market, determining its development prospects, it is possible to highlight the low consumption of drugs per capita, high competition level between companies producing drugs with relatively small market volume, the imbalance in the market growth in monetary and natural aspects, low share of innovative drugs, low business profitability, the lack of government funding, and high import dependency [5].

In harsh competitive environment conditions on the national pharmaceutical market, substantiated and timely adoption of managerial and production decisions to find and develop promising market niches, form competitive positions and unique advantages of drug production, coordinate of assortment and marketing strategies, are the main components of successful activity of pharmaceutical companies, enterprises and organizations.

3. Analysis of recent studies and publications in which a solution of the problem and which draws on the author

Recently, national scientists devoted their research to the problems related to the improvement of assortment policy, production program, innovation and investment activity of pharmaceutical companies. To date, studies concerning the state and prospects of the PE macro environment influence in Ukraine have been carried out [6]. The scientists justified the scientific and methodological approaches to the management of developments in the national pharmaceutical industry and to optimization of PE innovation portfolio financing $[7,8]$. 
4. Allocation of unsolved parts of the general problem, which is dedicated to the article

At the same time, aggravation of competition, financial instability and a significant saturation of the pharmaceutical market require the use of justified approaches for detection of promising market niches and the further development and implementation into drugs production based on comprehensive organizational, economic and marketing studies of the pharmaceutical market segments.

\section{Formulation of goals (tasks) of Article}

The aim of research was development of the product range renewal model for manufacturing pharmaceutical enterprise based on results of the complex organizational and economic, marketing and pharmacoeconomic studies.

\section{Statement of the basic material of the study (methods and objects) with the justification of the results}

For manufacturing enterprise formation of the products range is a complex process that should be carried out considering the influence of a number of social and economic factors, including economic indexes, population living standards, population demographic distribution, health, incomes, investment, system of pharmaceutical care organization in the country, etc. [9].

That is why, on the basis of generalization of the assortment policy formation practice in the PE and systematization of pre-made organizational- and economic, marketing and pharmacoeconomic studies, a model for the product range renewal at the manufacturing PE was proposed. The described model consists of five stages; each of them involves studies of organizational and economic orientation and performance indicators determination.

The first stage of the proposed model consists is the analysis of the existing methods and systems for the formation of the product range for manufacturing PE. Results of research have shown promising directions and mechanisms of product portfolio renewal in the national $\mathrm{PE}$ in order to increase their efficiency in conditions of increasing competition and market conditions.

According to the directions of the second stage of the efficient product range formation model in order to select the pharmacotherapeutic group that is being studied, we proposed the following marketing research:

- the analysis of the assortment structure of the studied market segment, which in our opinion allows determining the modern trends in the formation of nonsteroidal anti-inflammatory drugs market (NSAIDs), in particular the number of registered trade names and medicinal forms representing the studied group, composition of the manufacturers in the analyzed segment with the further calculations of their specific proportion [10].
- evaluation of NSAIDs value indexes with the following determination of market price conditions, price segments and economic accessibility of NSAIDs for the population. The given stage of research also involves the analysis of demand elasticity by price, which calculation allows determining the optimal correlation of prices and sales volumes.

The third stage of the mentioned model involves the search for market niches and selection of promising areas for product policy improvement, competitive analysis and identification of the market segments with the lowest competitive activity, which in our opinion is reasonable and expedient.

The planning of PE production and marketing activities, as well as creation of competitive advantages in the market, require reliable and comprehensive information about buyers, the analysis of their demand, advantages and behavior. Implementation of segmentation of drugs consumers makes it possible to analyze their individual needs and to develop effective marketing strategies that will ensure the drug competitive advantages [11]

The fourth stage of the model is a study of the peculiarities of NSAIDs using and trends in their changes, which is important when deciding on the expediency of development and implementation of a new drug, as it allows detecting the product of the promising and dynamically growing market segment.

Determination of the potential capacity of the pharmaceutical market target segment is one of the most relevant and perspective studies, which also belongs to the stage content. The results of this study on a new drug will allow you to calculate the optimal loading of production capacity, to develop an effective strategy for its promotion, and in the future to ensure a high economic effect from the implementation of the drug.

The results of this study concerning new remedy will allow calculating the optimal production capacity use, developing effective strategy for its promotion, and in the future ensuring high economic effect from the drug implementation.

At the last fifth stage, substantiation of the social and economic expediency of drug is necessary, with the further strategy development for strengthening the competitive positions of the new remedy. Economic efficiency assessment is to determine the cost price and profitability of the drug, the net present value, payback period and profitability index [12].

Therefore, it can be argued that research methods, performance indexes and, in particular, the research components, which are substantiated during the development of the planned model for the product range renewal at the manufacturing PE, allow optimizing the selection and realization of marketing studies strategy at the development stage and using the most effective methods of promotion at the drug implementation stage (Table 1). 
The model for the product range renewal at the manufacturing pharmaceutical enterprise

\begin{tabular}{|c|c|c|}
\hline Methods of research & Research content & Result indicators \\
\hline \multicolumn{3}{|c|}{ I Stage. The analysis of the systems of pharmaceutical enterprises product policy formation } \\
\hline \multirow[b]{2}{*}{ Content-analysis } & $\begin{array}{l}\text { - Analysis and generalization of the } \\
\text { existing methods for PE product portfo- } \\
\text { lio formation }\end{array}$ & $\begin{array}{l}\text { - promising directions for increasing the } \\
\text { management efficiency of the PE product } \\
\text { portfolio are identified }\end{array}$ \\
\hline & $\begin{array}{l}\text { - Research of the modern approaches to } \\
\text { formation of the national PE assortment } \\
\text { policy } \\
\text { - Benchmarking of PE production }\end{array}$ & $\begin{array}{l}\text { - estimated and qualitative indexes for } \\
\text { assessing the need for a drug }\end{array}$ \\
\hline \multicolumn{3}{|c|}{ II Stage. Complex marketing analysis of NSAIDs market } \\
\hline \multirow[b]{2}{*}{$\begin{array}{l}\text { Content-analysis of market- } \\
\text { ing research, retrospective, } \\
\text { comparative methods }\end{array}$} & $\begin{array}{l}\text { - The analysis of NSAIDs assortment } \\
\text { structure } \\
\text { - Estimation of NSAIDs cost parame- } \\
\text { ters }\end{array}$ & $\begin{array}{l}\text { - the level of NSAIDs group saturation; } \\
\text { - identified trends concerning formation of } \\
\text { the NSAIDs group range }\end{array}$ \\
\hline & $\begin{array}{l}\text { - Estimation of NSAIDs cost parame- } \\
\text { ters }\end{array}$ & $\begin{array}{l}\text { - NSAIDs price analysis with determina- } \\
\text { tion of price segments; } \\
\text { - NSAIDs demand elasticity calculation; } \\
\text { - the analysis of NSAIDs accessibility } \\
\text { indicators }\end{array}$ \\
\hline \multicolumn{3}{|c|}{ III Stage. Estimation of NSAIDs competition state in Ukrainian pharmaceutical market } \\
\hline $\begin{array}{l}\text { Statistical and mathematical } \\
\text { method }\end{array}$ & $\begin{array}{l}\text { - the analysis of NSAIDs competitive } \\
\text { positions in the national pharmaceutical } \\
\text { market }\end{array}$ & $\begin{array}{l}\text { - differentiation of drugs-outsiders groups, } \\
\text { remedies with weak, strong competitive } \\
\text { position and leaders according to the mar- } \\
\text { ket share size; } \\
\text { - NSAIDs strategic (competitive) posi- } \\
\text { tions in terms of the growth rate of their } \\
\text { market share. }\end{array}$ \\
\hline $\begin{array}{l}\text { Questionnaire; } \\
\text { Cluster analysis }\end{array}$ & $\begin{array}{l}\text { - NSAIDs customer advantages re- } \\
\text { search }\end{array}$ & $\begin{array}{l}\text { - social and demographic and behavioral } \\
\text { segmentation of NSAIDs users }\end{array}$ \\
\hline \multicolumn{3}{|c|}{ V Stage. Estimation of social and economic efficiency of the new drug implementation } \\
\hline Economic analysis methods & $\begin{array}{l}\text { - Estimation of economic expediency of } \\
\text { development and implementation of } \\
\text { drugs in manufacturing process }\end{array}$ & $\begin{array}{l}\text { - cost and profitability of drugs, income; } \\
\text { - indicators of investment expediency: net } \\
\text { present value, payback period and profita- } \\
\text { bility index }\end{array}$ \\
\hline Cost minimization method & $\begin{array}{l}\text { - Pharmacoeconomic research of the } \\
\text { drug use }\end{array}$ & $\begin{array}{l}\text { - NSAIDs efficiency and safety indexes; } \\
\text { - economic profit index when using of } \\
\text { analogues of Dexketoprofen subgroup }\end{array}$ \\
\hline SWOT-analysis & $\begin{array}{l}\text { - study of the factors of influence on } \\
\text { the Trade mark competitive potential } \\
\text { formation }\end{array}$ & $\begin{array}{l}\text { - development of the strategies to improve } \\
\text { TM "Keyver" competitive positions }\end{array}$ \\
\hline
\end{tabular}

\section{Conclusion}

On the basis of the results of organizational and economic and marketing studies of NSAIDs segment, the model for the product range renewal at the manufacturing PE was substantiated and developed.

Methods of analysis and product range evaluation, directions of the pharmaceutical market study at the choice of perspective market niches, criteria for econom- ic feasibility determination and investment attractiveness of drugs were detailed.

The developed product range renewal model on the manufacturing PE can be recommended as an effective support system for pharmaceutical organization grounded management decisions in marketing, which, we believe, will significantly reduce costs and increase the efficiency of business.

\section{References}

1. Stan ta perspektyvy rozvytku farmatsevtychnoi promyslovosti v Ukraini: Statystychnyi dosvid [Text] / V. F. Moskalenko (Ed.). - Kyiv: Karavella, 2007. - 149 p.

2. Bratishko, Yu. S. Suchasni metodychni pidkhody do otsinky staloho sotsialno-ekonomichnoho rozvytku 
farmatsevtychnykh pidpryiemstv Ukrainy [Text]: monohrafyia / Yu. S. Bratishko, O. V. Posylkina // Prostranstvennye aspekty razvitiya sotsial'no-ekonomicheskih sistem: ekonomika, obrazovanie i zdravoohranenie. - Opole, 2015. - P. $234-240$.

3. Kubyshyna, N. S. Metodyka rozrobky stratehichnoho naboru tovariv na promyslovomu rynku [Text] / N. S. Kubyshyna // Ekonomichnyi visnyk NTTU «KPI». - 2010. - Issue 7. - P. 171-178.

4. Meshalkina, S. Yu. Otsenka effektivnosti sistemy upravleniya tovarnym assortimentom farmatsevticheskih organizatsiy Dal'nevostochnogo regiona [Text] / S. Yu. Meshalkina, O. P. Gnatyuk // Vestnik Roszdravnadzora. - 2013. - Issue 3. - P. 40-44.

5. Pestun, I. V. Napriamky udoskonalennia Natsionalnoi likarskoi polityky v Ukraini za indykatoramy yii otsinky VOOZ [Text] / I. V. Pestun // Zbirnyk naukovykh prats spivrobitnykiv KMAPO im. P. L. Shupyka. - Kyiv, 2009. - P. 717-723.

6. Pestun, I. V. Stan ta perspektyvy vplyvu makrootochennia na diyalnist farmatsevtychnykh orhanizatsiy v Ukraini [Text] / I. V. Pestun, Z. M. Mnushko // Upravlinnia, ekonomika ta zabezpechennia yakosti v farmatsiy. - 2008. - Vol. 1, Issue 1. - P. 8-14.

7. Posylkina, O. V. Naukovi pidkhody do upravlinnia yakistiu doslidzhen i rozrobok u farmatsevtychniy haluzi [Text] / O. V. Posylkina, M. I. Sydorenko // Upravlinnia, ekonomika ta zabezpechennia yakosti v farmatsiy. - 2011. - Issue 4 (18). - P. 16-23.

8. Slobodianiuk, M. M. Naukovo-metodychni pidkhody do optymizatsiy finansuvannia innovatsiynoho portfeliu farmatsevtychnoho pidpryiemstva [Text] / M. M. Slobodianiuk, S. V. Zhadko, O. S. Samborskyi // Ukr. zhurn. klin. ta lab. med. - 2010. Issue 2. - P. 58-62.

9. Belyaevskiy, I. K. Marketingovoe issledovanie: informatsiya, analiz, prognoz [Text] / I. K. Belyaevskiy. - Moscow: Finansy i statistika, 2008. -319 p.

10. Mnushko, Z. M. Audyt rozdribnoi realizatsiy hormonalnykh likarskykh zasobiv [Text] / Z. M. Mnushko, V. V. Presniakova // Visnyk farmatsiy. - 2007. - Issue 2 (50). - P. 54-57.

11. Baeva, E. E. Analiz faktorov, vliyayushchih na psihologiyu pokupatelya lekarstvennyh sredstv [Text] / E. E. Baeva // Marketing v Rossii i zarubezhom. - 2007. - Issue 1 (57). - P. 20-23.

12. Zhadko, S. V. Metody analizu ta otsinky asortymentu likarskykh preparativ v systemi upravlinnia tovarnym portfelem vyrobnychykh farmatsevtychnykh pidpryiemstv [Text] / S. V. Zhadko, M. M. Slobodianiuk, N. M. Skrylova // Zbirnyk nauk. prats spivrobitnykiv NMAPO im. P. H. Shupyka. - 2009. - Issue 18. - P. 257-265.

Дата надходження рукопису 30.10.2017

Alla Kotvitska, Doctor of Pharmaceutical Sciences, Professor, Honored Worker of Science and Technology of Ukraine, Rector, National University of Pharmacy, Pushkinska str., 53, Kharkiv, Ukraine, 61002

E-mail: prorector@nuph.edu.ua

Volodymyr Kostiuk, Postgraduate student, Department of Social Pharmacy, National University of Pharmacy Pushkinska str., 53, Kharkiv, Ukraine, 61002

E-mail: volodymyr_kostiuk@ukr.net 